\title{
Divorce and the English Clergy c.1970-1990
}

\section{Abstract}

This article sheds light on how the Church of England discussed and managed divorce and remarriage in the later decades of the twentieth century. In the context of rapidly rising divorce rates, the Church's continued opposition to remarrying divorcees left it increasingly out of step with the expectations and experiences of large number of people. With the Church seemingly unable to offer forgiveness and a second chance to the many individuals whose marriages ended, the private misfortunes of clergy couples and the conduct of clergymen who failed in their role as moral exemplars came under ever greater public scrutiny than before. At the same time these issues revealed further dimensions to the gender inequalities present within the Church, as abandoned clergy wives were forced to campaign for rights to housing, financial assistance and counselling support. The article demonstrates how the Church became caught between a perceived need to defend the Christian ideal of marriage against the legacies of the permissive sixties, and the desire to promote itself as modern compassionate institution.

Keywords: Church of England; divorce; clergy; marriage

In 1994 the television dramatization of Joanna Trollope's bestselling novel, The Rector's Wife (first published in 1991), brought the subject of clergy marital breakdown into British living rooms. Trollope's novel offered a vivid portrait of the disintegration of the marriage of Anna and Peter Bouverie, a surname redolent of Gustave Flaubert's Madam Bovary. The Rector's Wife portrayed a relationship strained by the pressures of a limited income and the constant demands of parochial life. Having failed to be promoted to the post of archdeacon, Peter becomes emotionally withdrawn and increasingly demands that Anna conform to the standards of the traditional 'helpmeet' wife. Anna, meanwhile, 
actively rejects her identity as a clergyman's wife. Her rebellion is symbolised by her decision to take a part-time job in a nearby supermarket, but is ultimately manifested in her affair with one of three admirers whom Trollope introduces during the course of the novel. The adaptation by Channel 4 prompted a number of articles about clergy wives, clergy marriages and clergy affairs. ${ }^{1}$ In one example published in the Independent on Sunday, Rosemary Furber claimed that 'Trollope has it wrong ... The parish adulterer is more likely to be the vicar than his spouse'. The article reported the case of a clergyman who, for a period of nearly sixteen years, had persuaded his wife that 'she could not object to sharing him sexually with other women'. The marriage only came to end after one of the vicar's lovers came to live with the clergy couple at the vicarage in a disastrous ménage. ${ }^{2}$

The salacious details, both real and fictionalised, of failing clergy marriages can be located in a broader context of continuity and change in the nature of personal relationships in the second half of the twentieth century. Historians and other scholars have sought to understand the rapid shift from the high point of the popularity of marriage in the 1950s and 1960s to the dramatically rising divorce rates of the 1970s and 1980s, by which point a third of all marriages ended in divorce. ${ }^{3}$ Most recently, Claire Langhamer argues that an emotional revolution which helped foster greater commitment to marriage in the post-war decades contained the seeds of its own destruction from the 1970s onwards, because the heightened expectations of love and sexual pleasure which

\footnotetext{
${ }^{1}$ Mary Kirk and Tom Leary, Holy Matrimony? An Exploration of Marriage and Ministry (London, 1994), 112.

${ }^{2}$ Independent on Sunday, 27 February 1994, http://www.independent.co.uk/life-style/the-rectors-wife----herhusband-and-his-lovers-joanna-trollope-has-it-wrong-says-rosemary-furber-the-parish-adulterer-is-morelikely-to-be-the-vicar-than-his-spouse-1396823.html. Accessed 26 July 2014.

${ }^{3}$ For example see David Clark (ed.), Marriage, Domestic Life and Social Change: Writings for Jacqueline Burgoyne (1944-88) (London and New York, 1991); Jane Lewis, The End of Marriage? Individualism and Intimate Relationships (Cheltenham, 2001).
} 
were emphasised as integral to marriage were no longer containable within it. ${ }^{4}$ For Langhamer, the increasing centrality of love and sex to the discursive construction of marriage helps explain why attitudes towards adultery hardened, just as the practice appeared to have become more common. ${ }^{5}$ In what she describes as the 'sexually revolutionary' decade after 1968, Deborah Cohen suggests that not only did the occurrence of adultery continue to rise, but also that individuals, particularly men, increasingly chose to disclose their transgressions in an growing confessional culture in which privacy was reconfigured less in terms of 'family secrets' but instead as intrinsic to the 'autonomy of the individual'. This sense of privacy was played out in tension with a desire for openness and honesty which had come to be seen as essential in healthy relationships, but which proved a difficult ideal to live by. ${ }^{6}$

The adulterous behaviour of clergymen or their wives, or a failure to maintain commitment to the ideal of a life-long partnership, held a significance beyond the confines of the Church community. Though hardly immune to the broader trends highlighted above, clergy and their families were still expected to be moral exemplars in their parishes, and came to symbolise the Church's stance on personal relationships and conduct in the public mind. Whilst unflattering portrayals of clergy marriage had appeared in fiction since at least the age of Jane Austen, and details of clerical scandal regularly featured in national newspapers throughout the twentieth century, ${ }^{7}$ press

\footnotetext{
${ }^{4}$ Claire Langhamer, The English in Love: The Intimate Story of an Emotional Revolution (Oxford, 2013).

${ }^{5}$ Claire Langhamer, 'Adultery in post-war England', History Workshop Journal, 62 (2006), 86-115.

${ }^{6}$ Deborah Cohen, Family Secrets: The Things we tried to Hide (London, 2013), 235-38.

${ }^{7}$ See, for example, The Times' coverage of the consistory court proceedings of notorious vicars including Harold Davidson (1932), William Bryn Thomas (1961) and Thomas Tyler (1990); Callum G. Brown, Religion and Society in Twentieth-Century Britain (Harlow, 2006), 130; The Times, 16 March 1961, 8; Kirk and Leary, Holy Matrimony, 113.
} 
coverage of clergy marital problems took on a greater intensity and significance from the 1970s onwards. Jane Lewis and Patrick Wallis demonstrate how the 1969 Divorce Reform Act, which introduced partial no-fault divorce in 1971, rested on a compromise between Church and state, even though the legislation contradicted the Church's belief that divorce should only be permissible in cases of irretrievable breakdown. ${ }^{8}$ Despite, and perhaps because of this permissive moment, divorce became a touchstone issue for a growing anti-permissive lobby within the Church of England. Though it was a divisive issue, and many Anglicans were sympathetic to the plight of the divorced, the misgivings of the established Church towards legislative reform were manifested in its continuing opposition to the marriage of divorced persons in church. Whilst this period saw a considerable decline in church attendance and membership, weddings were a religious rite of passage which still mattered to an otherwise increasingly indifferent population, and were a means by which the Church could continue to engage with a national constituency. In the context of a growing number of second and subsequent marriages, the desire of newspaper editors to expose Church hypocrisy in the realm of sex and relationships, and the appetite for such stories amongst readers, was perhaps understandable.

As historians including Stephen Brooke and Lucy Robinson have recently shown, one of the legacies of the unfinished business of the permissive legislation of the 1960s was a highly fractious culture of sexual politics, particularly in the realms of homosexual rights, reproduction and women's liberation. ${ }^{9}$ Whilst emphasis has been placed on the

\footnotetext{
${ }^{8}$ Jane Lewis and Patrick Wallis, 'Fault, breakdown, and the Church of England's involvement in the 1969 divorce reform', Twentieth Century British History, 11 (2000), 308-32.

${ }^{9}$ Stephen Brooke, Sexuality, Family Planning, and the British Left from the 1880s to the Present Day (Oxford, 2011); Lucy Robinson, Gay Men and the Left in Post-War Britain: How the Personal got Political (Manchester, 2011).
} 
importance of 'authentic selfhood' in personal relationships in the immediate post-war decades, ${ }^{10}$ Brooke argues that in 'terms of the political treatment of sexual issues', a greater emphasis upon the 'self did not appear until the 1970s and 1980s, when it partially displaced the categories of class and family as important reference points. Indeed, as both Brooke and Deborah Cohen highlight, the latter decades of the twentieth century featured attacks 'upon the family and traditional sexual categorizations' which were rooted in gay and women's liberation as well as psychiatry. ${ }^{11}$ Whilst these reinforced the Church of England's perceived need to defend marriage and the family, its culture was also infused by a sexual politics which often defined the Church's public image. This included the campaigns for greater vocational rights for women within the Church, which were matched by demands for greater economic entitlements and an end to the assumptions which tended to incorporate clergy wives into their husbands' profession. ${ }^{12}$ Alongside a greater emphasis on women's rights within the Church came increased scrutiny of the conduct of clergymen. Recent scholarship has challenged linear accounts of the feminisation of religion in the nineteenth and twentieth centuries, and investigated the ways in which faith cultures influenced the 'formation of men as gendered and sexual beings'.13 Lucy Delap and Sue Morgan highlight the problems some clergy encountered

\footnotetext{
${ }^{10}$ Becky Conekin, Frank Mort, and Chris Waters (eds), Moments of Modernity: Reconstructing Britain 1945-1964 (London, 1999); Claire Langhamer, 'Love, selfhood and authenticity in post-war Britain', Cultural and Social History, 9 (2012), 277-97; Frank Mort, 'Social and symbolic fathers and sons in postwar Britain', Journal of British Studies, 38 (1999), 353-84.

${ }^{11}$ Brooke, Sexuality, 11; Cohen, Family Secrets, 212-40.

${ }^{12}$ Neil Armstrong, “'I insisted I was myself”: clergy wives and authentic selfhood in England c.1960-1994', Women's History Review, 22 (2013), 995-1013.

${ }^{13}$ Lucy Delap and Sue Morgan, 'Introduction: men, masculinities and religious change in post-Christian Britain', in Lucy Delap and Sue Morgan (eds), Men, Masculinities and Religious Change in Twentieth-Century
} 
in 'establishing a viable clerical masculinity' in relation to the hostility ordained men experienced both within and without the Church. Whilst the clergy experienced increasing challenges to their authority from lay Christians, longstanding working-class antipathy was often framed in terms of priests having 'insufficient masculinities', including the inability to earn a family-supporting wage ${ }^{14}$ Consequently, the failure of clergy marriages may have played upon these wider anxieties.

This article explores how the causes and consequences of clergy divorce were discussed and debated from the implementation of the 1969 Divorce Reform Act to the passage of the Clergy (Ordination) Measure (COM) in 1990, a piece of Church legislation which allowed divorcees to become ordained. Drawing upon evidence from the Church of England General Synod, Anglican newspapers, parliamentary debates and the national media, the article emphasises how the personal and professional lives of the clergy were deeply intertwined, resulting in a tendency for the Church's politics of sexuality to be played out through the private lives of its personnel. It highlights how ill-prepared the Church was for rising numbers of clergy divorces in structural terms. This was linked to deeply embedded gender inequalities within the Church, which were only partially overcome by growing female agency. In light of the Church's recent management of a range of issues including gay marriage and the ordination of women bishops, the article reveals important insights into the failure of the Church to come to terms with modern sexuality and gender equality in the recent past. It demonstrates an institution caught between the contradictions of trying to uphold a distinct set of values against the perceived legacy of the 'sixties' while endeavouring to become a modern compassionate organisation influenced by therapeutic culture. However, it is important to strike a note

Britain (Basingstoke, 2013), 1; Yvonne Maria Werner (ed.), Christian Masculinity: Men and Religion in Northern Europe in the 19 $9^{\text {th }}$ and $20^{\text {th }}$ Centuries (Leuven, 2011).

${ }^{14}$ Delap and Morgan, 'Introduction', 18-19. 
of caution. Recent work by Tim Jones on the Church of England from the mid nineteenth to the mid twentieth centuries emphasises how it absorbed new ideas from feminism and sexual science, where new female voices played a transformative role. ${ }^{15}$ This article provides evidence of this process continuing in the later decades of the twentieth century, yet the rapid pace of social change since the 1960s posed a distinct challenge to the Church as secularisation, demographic revolution and women's increasing economic autonomy proceeded hand in hand. ${ }^{16}$ Progressive voices within the Church continued to be heard, but their transformative potential was challenged by an increasingly anti-permissive atmosphere in the later decades of the twentieth century.

The article begins by examining how the Church community first acknowledged and then discussed the rising incidence of clergy marital breakdown in the 1970s and 1980s. The failure of a clergy marriage was often viewed as the result of professional stress, but in ways which seemed to absolve individual responsibility when adultery had occurred, particularly for the priest. The focus of the article then shifts to the formation of the Broken Rites pressure group in 1983, and its campaign to highlight how the Church of England often failed to offer emotional, material and spiritual support to clergy wives who were abandoned by their husbands. The final section demonstrates how the spectre of a failed clergy marriage informed the protracted debates on the COM during the 1980s. These debates situated women's rights within the Church within a broader discussion over whether the Church should allow divorced people to remarry in a church, and how divorce affected the careers of ordinands and priests. Though much of the dialogue was centred on the moral conduct of men, women remained at the heart of tensions within the Church over how to address the permissive legacy of the 1960s.

\footnotetext{
15 Timothy Willem Jones, Sexual Politics in the Church of England 1857-1957 (Oxford, 2012).

${ }^{16}$ Callum G. Brown, Religion and the Demographic Revolution: Women and Secularisation in Canada, Ireland, UK and USA since the 1960s (Woodbridge, 2012)
} 


\section{The Breakdown of Clergy Marriages}

From the late 1960s onwards there was intense debate within and without the Church of England over the Christian doctrine of marriage. Convocation rulings of 1938 and 1957 advised that divorced persons should not allowed to marry in church. Progressive voices within the Church were concerned that its rules on marriage discipline were increasingly out of step with the realities of ordinary people's lives. In 1971 the report of the Root Commission concluded that there were circumstances in which a second or subsequent marriage could be solemnised in church. It was recognised that despite good intentions first marriages did fail, and subsequent unions could 'show such evident features of stability, complementarity, fruitfulness, and growth as to make them comparable with satisfactory first marriages'. ${ }^{17}$ This reflected popular attitudes to marriage in the post-war decades, where heightened expectations placed greater emphasis on love, mutuality and personal growth than ever before, but inevitably resulted in greater disappointment when individual experience failed to match these ideals. ${ }^{18}$ Whilst the Church gradually came to recognise marriage as a personal relationship rather than an institution, there remained considerable Anglican opposition to greater tolerance of divorce and remarriage. This was inevitably framed by concern over rising divorce rates and the perceived consequences of the 1969 Divorce Reform Act. ${ }^{19}$ These concerns led the General Synod to narrowly reject the recommendations of the Root Commission during a series of debates held in 1973-74, as well as similar findings by the Lichfield Commission which

\footnotetext{
${ }^{17}$ Marriage, Divorce and the Church: The Report of a Commission appointed by the Archbishop of Canterbury to Prepare a Statement on the Christian Doctrine of Marriage (London, 1971), 71-2.

${ }^{18}$ Langhamer, English in Love.

${ }^{19}$ Marriage and the Church's Task: The Report of the General Synod Marriage Commission (London: 1978), 7.
} 
reported in 1978. During the latter session, the Archbishop of Canterbury, Donald Coggan, expressed his desire that the Church not remove the last brake from 'the rush down the divorce slope'. ${ }^{20}$ There was also concern amongst the Synod membership over a lack of consensus within the Church about changing its regulations on marrying divorcees, and anxiety that insufficient time had been allowed to consider the pastoral and theological consequences of such a change. ${ }^{21}$ The General Synod went on to support removal of the Convocation rulings in 1981, but again rejected it in $1985 .^{22}$ The Church of England eventually allowed the remarriage of divorced persons, under certain circumstances, in 2002, though by the mid-1990s in approximately ten percent of marriages conducted by the Church of England the priest ignored the Convocation rulings and allowed divorced individuals to wed. ${ }^{23}$ The large-scale prohibition on remarriage in Anglican churches had a direct impact on the nonconformist churches. For example, the number of divorced individuals remarrying in Methodist churches rose from thirty-four percent in 1974 to sixty-four percent twenty years later. The Methodist Church, however, also found the marriage of divorcees to be a controversial issue, and some ministers refused to conduct such marriages as a matter of conscience. ${ }^{24}$

\footnotetext{
${ }^{20}$ Church Times, 14 July 1978, 20.

${ }^{21}$ Church Times, 9 November 1973, 1, 24.

${ }^{22}$ G. I. T. Machin, Churches and Social Issues in Twentieth-Century Britain (Oxford, 1998), 218-20; Report by the Ecclesiastical Committee upon the Clergy (Ordination) Measure, 1988/89 HC 361, 9.

${ }^{23}$ Timothy Woods, 'Marriage after divorce: the challenge for the Church of England', Islam and ChristianMuslim Relations, 17 (2006), 347.

${ }^{24}$ Methodist Conference 2002 Report: Marriage in the Methodist Church, http://www.methodist.org.uk/downloads/conf-marriage-in-the-methodist-church-2002.pdf, accessed 6
} August 2014. Britain's transformation towards a multi-faith society also increased the extent to which alternative spiritual doctrines of marriage were present in which divorce and remarriage were equally problematic. For a discussion of contrasting Islamic and Christian approaches to marriage and divorce in 
The Lichfield Report recognised that structural changes in economic and family life had placed new pressures on marriages. Furthermore, the clergy were not exempt from marital problems. The report acknowledged an 'increased incidence of marriage breakdown among the clergy', emphasising that the 'nature of a priest's work in particular often subjects his marriage and his family to strain and stress, whether because the parsonage is "open house" to the parish or because of the impossibly long hours many clergy work ${ }^{25}$ This acknowledgement mirrored discussion ongoing within the Church community for more than a decade. Since the mid 1960s articles about and letters from clergy wives had regularly appeared in the church press. Debates about the nature and role of the clergy wife in this period suggested a growing tension between wives' expectations of marriage and the reality of life at the vicarage, but also that Church and laity continued to expect an 'unpaid curate' model of behaviour which some wives felt suppressed their own sense of selfhood. ${ }^{26}$ Consequently, changing roles and expectations placed new pressures on clergy marriages, exemplified by The Rector's Wife, in a period in which divorce was becoming easier to obtain and, at least by secular standards, gradually losing its social stigma. However, for understandable reasons relatively few of the clergy and wives who took part in these debates revealed personal details of a marital crisis or breakdown, and in any case this was not the inevitable outcome of marital pressure. Those who did share personal details did so anonymously. For example, the appointment of a Church marriage commission in 1971 prompted 'Priest' to comment in the Church Times that 'I have experienced ten years of happiness

\footnotetext{
the early twentieth century, see Gail Savage, 'More than one Mrs. Anwaruddin: Islamic divorce and Christian marriage in early twentieth-century London', Journal of British Studies, 47 (2008), 348-74.

${ }^{25}$ Marriage and the Church's Task, 18-19, 74.

${ }^{26}$ Armstrong, 'I insisted I was myself'.
} 
with my first wife, who died; and ten years of unhappiness with my present wife'. ${ }^{27}$ Amongst several replies in the letters pages, 'Yet another Priest' revealed that he and his wife 'spent three years propping up a façade of respectability behind which we at first tried to mend the marriage, but soon descended into a sheer hell of constant bickering, hatred and recrimination where at times I had to force myself to give my wife Communion ... My wife and I have now lived apart for two years, and divorce proceedings are under way'. ${ }^{28}$

One notable exception to these anonymous confessions occurred in 1975 when Bill Pears, Rector of Trusham, Devon, revealed details of how his seventeen-year marriage had ended whilst filming a television 'epilogue' for the south-west regional station Westward TV, a story which was subsequently carried by the Nens of the World. Pears, whose marriage ended in 1968, told viewers: 'I was sitting at my desk reading when my wife popped her head round the door and said she was leaving me for someone else ... I must take the blame for her going because I had forgotten her needs'. ${ }^{29}$ A decade later, Hilary Devereux interviewed a number of clergymen whose marriages had failed. Hindsight led several to reach similar conclusions to Pears, as Devereux summarised: 'they had been very inexperienced, had known far too little about women or marriage before they had taken this step. Their expectation of marriage had been based on their own childhood'; they had become 'absorbed in parish work and did not realise ... their wives were unhappy in the parish'. ${ }^{30}$ These revelations, played out to both a Church and a national audience, demonstrated all too clearly that clergy marriages were experiencing

\footnotetext{
${ }^{27}$ Church Times, 14 May 1971, 12.

${ }^{28}$ Church Times, 28 May 1971, 12.

${ }^{29}$ News of the World, 28 September 1975, 11.

${ }^{30}$ Hilary Devereux, The Breakdown of Clergy Marriages: A Study of the Problems Experienced by Clergy When Deserted by their Wives (London, 1985), 47-8.
} 
similar issues to those highlighted in recent studies by Cohen and Langhamer. This evidence suggests that clergymen were slow to recognise their wives' heightened expectations of personal fulfilment and mutual growth, whilst clergy wives were more willing to acknowledge and address their problems. In such cases, it is likely that the burden of the Church's defence of the institution of marriage weighed heavily on the conscience of the couples involved. At the same time, the acknowledgement of marital neglect seemed to imply a tension within contemporary models of clerical masculinity between vocational demands and new expectations of clergy as husbands.

Devereux's study, conducted on behalf of the House of Bishops, focussed on clergymen who had been deserted by their wives. However, in cases where marital breakdown followed adultery, as stated by Rosemary Furber, there was an assumption that the adulterer was more likely to be the vicar than his wife. In an article for the Church Times published in 1973 entitled 'Parsons at risk', Michael Smout argued that the temptation of clergymen to 'overwork' was such that 'sometimes ... he is drawn apart from his wife. He is then peculiarly open to a relationship with another woman ... it can start off innocently enough as a pastoral concern for someone in the congregation'. ${ }^{31}$ Though not all readers of the Church Times took Smout's warning seriously, these ideas gradually gained currency. Later in 1985 the clergyman Wesley Carr made a similar point in an advice book when he linked sexual misbehaviour to situations where 'the framework of authority within which the parish priest is located is felt to be diminishing'. Carr argued that since the clergyman's person and his professional role were so closely intertwined, various pressures might lead to an attempt at self-destruction, which could include adultery. ${ }^{32}$ Even when entirely innocent, pastoral care in the parish could contribute towards clergy marital problems. In 1987, David and Joyce Huggett, a clergy

\footnotetext{
${ }^{31}$ Church Times, 23 November 1973, 8.

${ }^{32}$ Wesley Carr, The Priestlike Task (London, 1985), 63. See also Kirk and Leary, Holy Matrimony, 99.
} 
couple based in a Nottingham parish, explained this point in an episode of ITV's Encounter documentary series. When David noted how the pastoral care of parishioners could involve emotional intimacy and physical touch, Joyce candidly revealed that such situations had prompted her to feel jealously and bitterness and to emotionally withdrawal from her husband. The Huggetts were uniquely placed to comment on this, having previously experienced marital problems during which Joyce became suicidal. Following counselling and recovery, they went on to develop marriage enrichment weekends for fellow clergy couples. ${ }^{33}$

When the Huggetts first began to encounter difficulties in their marriage, the Church provided relatively few supporting resources. In 1978 the Lichfield Report recommended that 'in ordination and post-ordination training attention should be given to the priest's family life' ${ }^{34}$ By the early 1990s provision in this area was still considered inadequate, ${ }^{35}$ but a patchwork of initiatives had developed since the late 1970s. Alongside the Huggetts' own efforts, some dioceses appointed advisory committees, whilst related organisations including the Association of Pastoral Care and Counselling developed programmes designed to counsel clergymen and their wives. ${ }^{36}$ The emergence of specialist care for the clergy and their wives was dependent on several trends, including the role of the churches in the development of relationship counselling more broadly, and the subsequent growth of counselling as the dominant paradigm in pastoral care in

\footnotetext{
${ }^{33}$ Encounter: Great Expectations (Central Television, broadcast 1 February 1987).

${ }^{34}$ Marriage and the Church's Task, 74.

${ }^{35}$ General Synod July Group of Sessions, Report of Proceedings, vol. 24 no. 2 (1993), 638.

${ }^{36}$ Church Times, 19 January 1979, 4; 18 January 1980, 3; Church of England Newspaper, 13 June 1980, 9.
} 
the 1970s and 1980s. ${ }^{37}$ A part of this process was the emergence of a number of organisations with links to the Church which attempted to bring together theology, insights from the human sciences and empirical evidence. ${ }^{38}$ One early initiative was undertaken by the Clinical Theology movement which emerged under the leadership of Frank Lake in the 1960s in order to incorporate aspects of psychological practice into the Church's pastoral care. Part of the syllabus developed by the Clinical Theology Association focused on the 'clergyman and his family'. ${ }^{39}$ By the later twentieth century the Church of England had effectively sanctioned the ideas promoted by the theologian Derrick Sherwin Bailey in the late 1950s and 1960s which emphasised a theology of sexual love, placing emphasis on marriage as a personal relationship rather than an institution, in which (non-procreative) sex was an expression of love rather than sinful desire. ${ }^{40}$ As the Lichfield Report stated, marriage 'is first and foremost a personal relationship ... based on a free commitment to live and grow together'. ${ }^{41}$ Also influential here was the work of the Roman Catholic psychiatrist and marriage guidance counsellor Jack Dominian, who had contributed to the Anglican Church's 1971 report on Marriage, Divorce and the Church and provided oral evidence to the Lichfield Commission. ${ }^{42}$

\footnotetext{
${ }^{37}$ Jane Lewis, David Clark and David Morgan, Whom God hath Joined Together: The Work of Marriage Guidance (London, 1992), 41 and chapter 4; Home Office, Marriage Matters: A Consultative Document by the Working Party on Marriage Guidance (London, 1979).

${ }^{38}$ Paul Ballard, 'The emergence of pastoral and practical theology in Britain', in James Woodward and Stephen Pattinson (eds), The Blackwell Reader in Pastoral and Practical Theology (Oxford, 2000), 66-7.

${ }^{39}$ Deborah Gaunt, 'First evaluations', in Gladys Keable (ed.) Such As We Are: Parsons' Wives and Parsons' Families (London, 1967), 21.

${ }^{40}$ Derrick Sherwin Bailey, The Mystery of Love and Marriage. A Study in the Theology of Sexual Relations (London, 1952); Lewis, Clark and Morgan, Whom God, 115, 159.

${ }^{41}$ Marriage and the Church's Task, 63.

${ }^{42}$ Marriage and the Church's Task, 72, 183. Dominian also advised the Huggetts on their marital problems.
} 
Dominian argued that the minimum needs and expectations of a couple could be understood in terms of sustaining, healing and growth, where 'sexual intercourse is the act which confirms the nurturing, healing and growth so far and gives hope and meaning for its continuation the day after. ${ }^{43}$ By the 1980 s clergy couples were being told with increasing frequency that sex was a site of both marital harmony and dysfunction.

There is evidence to suggest that a number of clergy couples felt in need of counselling, though the extent to which their problems had sexual causes or consequences is not known. For example, in 1981, Michael Walker, the vicar of St. Mary's, Bury St. Edmunds, received a hundred replies from a questionnaire he sent out to two hundred priests based in over thirty dioceses. Seventy-three indicated a desire for pastoral counselling. When asked what issues were important, forty-eight named marriage problems, and forty-six said 'relationships'. However, half of those in need of counselling had not been able to access any resources in their diocese. ${ }^{44}$ This prompted Walker to introduce a private members' motion to the General Synod in February 1982 which called upon 'the House of Bishops to provide pastoral care which will meet the needs of the clergy and their families bearing in mind the particular problems of those engaged in a pastoral ministry'. The debate, framed by the spectre of clergy marital breakdown, placed great emphasis on the pressures of the clerical profession which were increasingly understood in medical terms. Walker quoted a letter from Peter Nicholson, the secretary of St Luke's Hospital for the Clergy, who stated that 'we find we are dealing with a growing number of men who are suffering from depression and psychological disorders which are probably the underlying cause of ultimate physical illness', whilst the Rev M. F. Leigh of Derby highlighted the 'increase of stress illness in the clergy'. ${ }^{45}$ By the

\footnotetext{
${ }^{43}$ Catholic Herald, 3 January 1975, 4.

${ }^{44}$ Church Times, 26 June 1981, 2.

${ }^{45}$ General Synod February Group of Sessions, Report of Proceedings, vol. 13, no. 1 (1982), 224-29
} 
end of the decade 'clergy stress' had become a recognisable term promoted in published studies and guide books. ${ }^{46}$ It helped the Church conceptualise how it might explain, legitimate and prevent clergy marital breakdown, though in ways which seemed to mitigate fault. This was highly pertinent in the context of the gender inequalities embedded in the structures of the Church, which left clergy wives particularly vulnerable to the consequences of marital failure in emotional, material and spiritual terms. It became increasingly apparent little was being done to help wives whose relationships did fail. Consequently, the Church's responsibility for the welfare of separated and divorced wives became an important feature of how clergy marital breakdown was discussed and understood, largely due to the activities of the Broken Rites association.

\section{Broken Rites}

The 1970s and 1980s witnessed the growth of women's agency within the Church of England, which was manifested in the re-emergence of campaigns for female ordination and the development of Christian feminism. Though not all Anglican women were committed to more radical forms of equality, the increasing prevalence of clergy marital breakdown cast new light on the lack of entitlements extended to wives who had often made considerable personal sacrifices in service to the Church. In the 1980s abandoned clergy wives were emboldened to seek new rights of citizenship within the Church. They both exploited and were exploited by a national media keen to highlight the personal failings of the clergy in contrast to their ideal as moral exemplars. Whilst the emergence of Broken Rites can be seen as part of a broader campaign for gender equality within the Church, it was framed by longstanding anxieties concerning the ability of clergymen to perform 'traditional' masculine roles such as supporting the family. Even more

\footnotetext{
${ }^{46}$ For example, see Mary Ann Coates, Clergy Stress: The Hidden Conflicts in Ministry (London, 1989).
} 
problematically for the Church, this failure was seen to encompass both individual clergy and the institution as a whole. Consequently, the Church reacted uneasily and sometimes unsympathetically to the agency of wives, but gradually and unevenly began to accommodate their demands.

The problems experienced by clergy wives during marital breakdown first came to light in the late 1970s. In July 1979, Judy Veale, the chairman of the Plymouth and District Association for Girls' Welfare, wrote to the Church Times to express her 'deep concern regarding the lack of support from official Church sources for deserted clergy wives and their children ... The $\mathrm{C}$ of $\mathrm{E}$ is not compelled, and in my experience does not accept, responsibility for these women or their children'. Veale highlighted that 'the deserted wife has approximately three months in which to vacate Church property after her husband has resigned his living', at which point the 'loss of the family home often means removal from the neighbourhood and changing schools for children, which increases the already heavy burden for the mother'. Veale also described the reliance of some wives on state welfare if they had no other means of support. ${ }^{47}$ The collapse of a clergy marriage could leave a clergy wife extremely isolated and vulnerable if she did not have a strong network of family or friends beyond the Church. In the 1970s policies were created to assist one-parent families in material terms, and housing became 'an accessible social right' for single mothers. ${ }^{48}$ However, clergy wives whose marriages failed in the 1980s could still face considerable financial difficulty during a period of severe emotional distress. In an independent report unsanctioned by the Church and made public in December 1982, the Labour MP and Anglican layman Frank Field provided evidence of the inconsistent treatment of divorced or separated clergy wives by the Church of

\footnotetext{
${ }^{47}$ Church Times, 13 July 1979, 13.

48 April Gallwey, 'Lone motherhood in England, 1945-1990: economy, agency and identity', PhD thesis, University of Warwick, 2011, 164.
} 
England. Field's attention was drawn to the issue during the discussion of the Clergy Pensions (Amendment) Measure in parliament, which revealed that deserted clergy wives were not entitled to pension provision, nor were they eligible for schemes which allowed retired clergy mortgage loans to purchase retirement homes. ${ }^{49}$ His report was based on the completed questionnaires of twenty-four divorced or separated clergy wives who responded to an advertisement placed in the weekly Anglican newspapers. The majority of women in this small, self-selecting sample had been married for a period of fifteen years or more (and none had been married for less than five years) and were responsible for children. They were asked a series of questions relating to the financial support they received from their husbands, the Church and its associated charities; their housing situation; how they were treated by the local congregation; and the support they received from senior clergy. At the time of separation, seven wives received no financial help from their husbands, whilst for the remaining number assistance was often in small amounts and had to be requested or paid on a magistrate's order. When asked how much help they currently received, eleven wives mentioned they received nothing in the way of assistance. The majority of the sample group did not gain immediate or subsequent financial help from the Church, and those who did revealed widely divergent practices across the dioceses of England. In addition, only a small number were in receipt of aid from Church charities. In relation to housing, seven of the wives were formally evicted by the Church, with the notice period varying between 'the end of the month' and three months. Thirteen wives reported that on leaving Church property 'they had nowhere else to go', and seven became the responsibility of the local authority, and the Church itself only found new accommodation for two families. The experience of these women diverged sharply in relation to their treatment by the local congregation. Half of

\footnotetext{
${ }^{49}$ Parliamentary Debates (Commons), 25, 17 June 1982, 1179-84.
} 
respondents replied that they had received 'no help at all', but the remaining half provided both practical help and in some cases 'great love and concern'. A more variable response was given in relation to help and support provided by rural deans, archdeacons and bishops. Whilst several examples of support were cited, eleven wives stated that they gained no help from senior clergy. Furthermore, some wives felt that they were an embarrassment which the Church hoped would disappear, in many cases by leaving the diocese. As one respondent commented, having received a suggestion from her archdeacon that she move to London: 'I always had the feeling he wanted to be rid of me'. In some cases wives also felt 'there was a closing of the hierarchy's ranks around their husbands', as one explained: 'It seemed (that) those in authority protected my husband like a rugby player whose shorts gave way during the game! ${ }^{50}$

Consequently, Field's report took a very critical tone towards the Church of England. It was framed by the assumption that clergy wives had given many hours of labour and service to the Church. This was confirmed by Field's sample of clergy wives. Almost all spent some amount of time undertaking parish work, ranging from 'a few hours each day' to 'it was my whole life'. With this moral claim established, Field was able to criticise the Church not only for the inconsistent treatment of wives, but also for not living up to its own standards of compassion and morality: 'because the Church in its teaching emphasises certain non-worldly moral views, such worldly behaviour as its treatment of deserted clergy wives leaves it open to ridicule'. These criticisms formed the basis of Field's recommendation that deserted clergy wives be given rights to housing and pensions as well as access to a 'comprehensive service' of counselling and financial advice. $^{51}$

\footnotetext{
${ }^{50}$ York Minster Library (YML), pamphlets collection, C53.2 FIE, Frank Field, 'Walking by on the other side? A report on the plight of separated clergy wives' (1982), 2-15.

${ }^{51}$ YML, Field, 'Walk by', 8-9, 16-20.
} 
In 1983 Field became president of the newly formed Broken Rites. It owed its existence to the agency of a small number of wives who had 'weathered a broken clergy marriage' and come together for 'help and mutual encouragement'. Isobel Pain emerged as an informal leader of the group, and wrote to the Church Times that year to emphasise the need to resolve issues of housing, finance and pastoral care. ${ }^{52}$ In their campaign, Broken Rites were able to command the attention of a national media all too willing to listen to cases of the personal failings of the clergy. For example, Pain's story was featured on BBC1's Sunday Night programme in December 1982, both the Guardian and The Times published stories about former clergy wives in the early to mid 1980s, and there were also features on Woman's Hour on Radio 4 and in Woman magazine..$^{53}$ In the hands of the tabloid press this situation inevitably portrayed clergymen in a very negative light. For example, though the story was later denied, 1983 the Daily Mirror reported that Alison Crosthwaite had set up a telephone hotline for clergy wives abused by their husbands under the headline, 'War on vicars who batter their wives', supported by 'One moved a young choirgirl into his home'. ${ }^{54}$

The considerable media exposure created a climate of urgency in which the Church of England began to take measures to address these problems. In February 1983 the General Synod supported a private member's motion which asked the standing committee to consider a means of making available accommodation and practical provision for a wife and children who must move out of a parsonage. ${ }^{55}$ This provided the

\footnotetext{
${ }^{52}$ Church Times, 25 June 1982, 13.

${ }^{53}$ Guardian, 30 August 1982, 4; 5 December 1982, 2; 16 April 1985, 4; The Times, 18 April 1984, 11; Pauline Morrell, 'The way it was', in Pauline Druiff and Gill Murray (eds), The Story of Broken Rites (Newport, 2003), 9.

${ }^{54}$ Daily Mirror, 5 September 1983, 14; Church of England Newspaper, 16 September 1983, 3.

${ }^{55}$ Church Times, 18 February 1983, 2.
} 
impetus for the establishment of a House of Bishops working group on pastoral care and practical provision during the breakdown of clergy marriages. Even when attempting to alleviate the situation, the Church of England still managed to pay insufficient attention to its sensitive nature. In May 1984 Pauline Morrell, the secretary of Broken Rites, complained publicly that wives had been 'asked to describe their personal stories' in the presence of the entire working group, noting that the association had not been consulted on how to gather evidence from its members in the 'small world' of the Church, where 'one is sure to know somebody who knows someone in the group'. ${ }^{56}$ Despite these tensions, in 1985 the report of the working party recommended the appointment of a bishop's visitor in each diocese to provide pastoral care and ensure that deserted clergy wives had access to financial advice and assistance. ${ }^{57}$ The first visitors were appointed later that year. ${ }^{58}$ The report also led to a number of clerical charities including the Corporation of the Sons of the Clergy being allowed to provide financial help for deserted wives. The growing currency of 'clergy stress' led the working party to conclude that the Church had a greater responsibility than other employers as clergy marital breakdown was closely associated with problems deriving from the nature of the profession, in which wives potentially stood to lose their marriages, homes, income and the 'whole network of the local Church community'. ${ }^{59}$ Consequently, the report was a stimulus to new initiatives developed at regional and local level aimed at alleviating clergy stress, including the north-western Inter-Diocesan Counselling Service which was

\footnotetext{
${ }^{56}$ Church Times, 11 May 1984, 3.

${ }^{57}$ Lambeth Palace Library (LPL), London, GS Misc 22, Church of England, 'The breakdown of clergy marriages: pastoral care and practical provision: A report by the House of Bishops' (1985).

${ }^{58}$ Henrietta Telford, 'Bishops' visitors: A response by the Church of England to clergy marriage breakdown', in Druiff and Murray, Story of Broken Rites, 20-22.

${ }^{59}$ LPL, 'Breakdown', 4-5.
} 
established in $1985 .{ }^{60}$ Whilst the greater commitment to counselling provision can be seen as a victory for the Broken Rites association, its capacity to reduce clergyman's individual culpability in cases of adultery and desertion proved problematic for wives. Broken Rites may have been founded on a need for emotional and financial support for divorced and separated clergy wives, but its cause became inextricably linked with broader debates played out in the national arena concerning the personal conduct of the clergy and the Church's attitude towards divorce.

\section{The Clergy (Ordination) Measure}

The rising number of clergy divorces drew attention to the possibility of remarried clergymen continuing in their vocation whilst their former spouses were still alive. This was deeply problematic in the context of the continued objection to divorcees remarrying in a church. Consequently, the reform of inconsistent regulations, which forbade ordination to candidates who were either divorced or married to a divorcee, became the focus of wider debates about the Church's position on marriage in the 1980s. A relatively obscure piece of Church legislation brought into sharp relief the tension between the wish to defend a traditional Christian doctrine of marriage against permissiveness, and the desire to promote a more caring Church relevant to the needs of the age. The debates were also informed by the Broken Rites agenda, which alongside the need for pastoral support also sought greater consistency in the application of ecclesiastical discipline in cases of personal misconduct.

The availability of pastoral care, both for married and separated couples, was clearly important to members of Broken Rites, but the way in which it was often framed by a discourse of clergy stress which seemed to downplay individual culpability was

\footnotetext{
${ }^{60}$ Church Times, 7 March 1986, 3.
} 
problematic for the group. Consequently Broken Rites also sought a 'clearer statement by the churches as to what the vows taken by clergymen at the sacraments of ordination and marriage should express'. ${ }^{61}$ This was particularly the case when personal misconduct did not seem to have any impact on a clergyman's career, and moral failings seem too easily blamed a lack of institutional support. In 1984 Pauline Morrell argued that many husbands:

have told a great many lies ... Our correspondence reveals stories so similar that they are staggering. The same phrases occur again and again. Most commonly, the husbands claim they are "not supported enough in their ministry." There is an element of fantasy in all this, and a lot of deceit and self-deceit. They always have plausible sounding excuses to justify what they do - in their own eyes if not in anyone else's. I think there are many in orders who should never have been ordained. Many of us are disturbed by the way our husbands have been allowed to continue their ministry and by the way that, if one bishop will not accept a man, another will. I myself am uncomfortable about the implications for ministry when a man who has treated his wife in such a way is allowed to continue. ${ }^{62}$

A clergyman could be deprived of his benefice if a divorce was 'granted against him on a finding of his adultery, desertion or intolerable conduct'. ${ }^{63}$ A divorce in itself was not grounds for a disciplinary proceeding. However, the situation was less clear if a clergyman subsequently remarried within the lifetime of his former spouse. Canon C.10,

\footnotetext{
${ }^{61}$ Church Times, 25 June 1982, 13; 4 February 1983, 3; 30 January 1987, 11; Pauline Druiff, 'Frank’s tea party and subsequent happenings', in Druiff and Murray, Story of Broken Rites, 14

${ }^{62}$ Church Times, 11 May 1984, 3.

${ }^{63}$ Marriage and the Church's Task, 107.
} 
which governs the admission and institution of the clergy, stated that a bishop may refuse to institute on the grounds that the 'said priest is unfit for the discharge of the duties of a benefice by reason of ... grave misconduct or neglect of duty in an ecclesiastical office, evil life, [and] by his conduct caused grave scandal concerning his moral character since his ordination'. ${ }^{64}$ When the Lichfield Commission considered this in 1978, they recommended that for divorced clergy, the 'primary consideration should be the consequences for his continued ability to carry out the office and work of the priest'. There were existing measures designed to deal with clergy who were failing to perform their role, including the Ecclesiastical Jurisdiction Measure of 1963, which allowed proceedings to be instituted against 'conduct unbecoming the office and work of a clerk in Holy Orders', ${ }^{65}$ and the 1977 Incumbents (Vacation of Benefices) Measure, which was intended to improve relations between clergy and their parishioners, as well as removing causes of estrangement. ${ }^{66}$ Whilst the Lichfield Commission were confident that these existing regulations were robust enough to deal with cases involving scandal and misconduct, it observed that there was much more vagueness and uncertainty in relation to divorced clergy in general. For example, it was argued that Canon C.10 could not reasonably be applied when a clergyman had divorced through no fault of his own, or when clergy proceeded to legally remarry. Furthermore, this logic led the Commission to address the inconsistency of regulations relating to ordinands and clergy. Before 1990, it was illegal for a person who had remarried to enter Holy Orders while the former spouse was still alive. This also applied if they had married a divorced person whose former

\footnotetext{
${ }^{64}$ Ecclesiastical Committee, 12.

${ }^{65}$ Ecclesiastical Jurisdiction Measure 1963, http://www.legislation.gov.uk/ukcm/1963/1. Accessed 26 March 2014.

${ }^{66}$ Marriage and the Church's Task, 107-8. Incumbents (Vacation of Benefices) Measures 1977 and 1993. Code of Practice, http://churchofengland.org/media/51392/ivbmcop.pdf. Accessed 26 March 2014.
} 
partner was similarly extant. However, this law did not apply to an ordained clergyman who remarried. The Commission concluded that 'the law on the marriage and divorce of ordinands and clergy is confusing, and, in some respects, doubtful', and advised that bishops be given discretion to ordain a man who had remarried or married a divorced woman in certain circumstances. At the same time, the Commission also recommended that bishops be granted discretionary powers over clergy in the same circumstances, because the 'bishop's power to refuse to institute in such a situation is not assured'. This was intended to avoid situations such as the one which arose in Dorridge in Warwickshire in the early 1970s. In January 1972 Philip English, the vicar of Dorridge, was advised to resign his living by the Bishop of Birmingham if he wished to remarry. The Bishop stated that he could not compel English to resign under the 1969 Divorce Reform Act, but urged him to recognise how his actions would contravene the Christian view of marriage. By the end of February English declared that he would not resign, but a month later gave way because of the division it had caused in the parish. ${ }^{67}$

These recommendations relating to the clergy took the Church of England over twelve years to implement. Following consultation in the dioceses a draft COM first appeared in 1982, but the debate in the General Synod was abandoned at this point to make more time for the key recommendation of the Lichfield Report that remarriage in church should be allowed. It subsequently became clear that confidence in the Church's ability to resolve the broader issue of remarriage had been misplaced, and a further draft measure on ordination emerged in 1985, and was approved the General Synod in 1987. When the COM was passed to the parliamentary Ecclesiastical Committee in 1988 serious concerns emerged, and the Ecclesiastical Committee took the unprecedented step of calling a joint conference with the legislative committee of the General Synod in April

\footnotetext{
${ }^{67}$ Church of England Newspaper, 21 January 1972, 5; 25 February 1972, 1; 24 March 1972, 6.
} 
1989. Though the Ecclesiastical Committee found the COM to be expedient by a narrow majority of ten to nine, it was defeated in the House of Commons in July, the first time a piece of Church legislation had been rejected in parliament since the introduction of synodical government in 1969. However, because the measure had been defeated at halfpast-three in the morning when only ninety-six MPs were present, it was allowed to be re-introduced in the following session of parliament, and 228 MPs voted in favour of the measure in February 1990, compared with 106 against. ${ }^{68}$

Why was the COM so protracted and controversial? Whilst delays were caused by technical and procedural matters, the COM also showcased tensions within the broader Church community. When the COM was debated in the General Synod and in Parliament, divisions emerged within the broader Anglican community which emphasised the problems the Church experienced in trying to maintain moral leadership and authority in English society. As well as focusing on divorce as a totemic representation of the permissive society, the COM also highlighted the rights of women within the Church. In opposing the recommendations of the Lichfield Commission in 1978, the Archbishop of Canterbury Donald Coggan told the General Synod that he believed that any relaxation of the rules governing the status of ordinands would 'lower the standard which people are entitled to expect of their parish priest'. ${ }^{69}$ Though his successor, Robert Runcie, became an ardent supporter of the COM, the requirement that clergy and their wives be moral exemplars to their local communities was a persistent theme of opponents of the measure throughout the 1980s. The doctrine of the 'indissolubility of Christian marriage', already weakened by the permissive legislation of the 1960 s, was perceived to further threatened by the measure. ${ }^{70}$ The notion that the

\footnotetext{
${ }^{68}$ Parliamentary Debates (Commons), 167, 20 February 1990, 882-906.

${ }^{69}$ General Synod, July Group of Sessions, Report of Proceedings, vol. 9, no. 2 (London, 1978), 782.

${ }^{70}$ Ecclesiastical Committee, 4.
} 
personal conduct of the clergyman must stand as a final line of defence against the ravages of the permissive society was articulated in a Synod debate in 1985 by Mrs M. Brown, a laywoman from Rochester, who argued that the 'Church should set the way and say "No" to these immoral acts, "No" to divorced clergy, "No" to divorced ordinands'. For Mrs Brown, the consequences of not taking a stand were obvious: 'How can a divorced man tell a young person what to do? The young person says, "Don't worry, Mum, the vicar's divorced, it's OK, I can do the same'. ${ }^{71}$

During the House of Commons debate in February 1990, the Conservative MP Hugo Summerson argued that there 'is a feeling of despair among many lay people ... the Church of England has gone wrong. It no longer provides the guidance that ordinary people expect'. Summerson's acknowledgement that religious authority rested on the ability to provide moral guidance partly explains why opposition to the COM was highest amongst the laity. Yet some voices in the debate recognised that the Church's growing therapeutic culture offered alternative vision of priesthood which might speak to constituencies beyond the committed worshipper. For example, in the 1989 Lords debate, Baroness Seear made the connection between the decline of the clergyman as the moral exemplar and the rise of the trusted counsellor: 'frankly, I do not particularly want to look up to my priest. However, I do want to be able to talk to him. When I talk to him, I hope that he can understand'. ${ }^{72}$ This attempt to shift the nature of authority towards expertise was not an easy experience. Adherents of the COM attempted to defend Christian values in the context of permissiveness, but also wanted to adapt a more caring and compassionate stance on relationships. Understandably, proponents had to re-emphasise their commitment to the Church's teaching on marriage, but also

\footnotetext{
${ }^{71}$ General Synod, November Group of Sessions, Report of Proceedings, vol. 16, no. 3 (London, 1985), 990-91.

72 Parlimentary Debates (Lords), 509, 3 July 1989, 1028.
} 
recognised that the 'witness of failure, forgiveness and renewal is crucial to the understanding of the gospel'. ${ }^{73}$ This rested partly on a refutation of the mutuality of blame in all examples of marital failure, and an insistence that cases existed 'where one of the partners ... is the victim of the personality and behaviour of the other party'. ${ }^{74}$ There was also a gradual recognition, linked to the growing emphasis on counselling in pastoral care, that unfortunate past experience could become the basis of expertise. As the Bishop of Liverpool, David Sheppard, observed in 1981: 'if the clergy include some of those who have experienced the pain and hurt of divorce in their lives and have remarried and have learnt something through that suffering and rebuilding, we might be more easily able to create that atmosphere in which people may shout for help'. ${ }^{75}$

Not all those who opposed the COM did so from a conservative stance on marriage. For example, Frank Field objected to the measure because he believed that allowing divorced candidates to become ordained placed them in a higher category of citizenship than the majority of English people who were still denied the right to marry in church after divorce. ${ }^{76}$ Field's commitment to equality within the Church included championing the rights of Anglican women as well as the laity. Proponents of the COM argued that it was necessary to solve manpower issues within the Church, because potential candidates of high quality were being put off from coming forward for ordination. ${ }^{77}$ In the second half of the 1980 s it was also recognised that the existing regulations debarred a number of deaconesses and other women from becoming ordained as deacons. This emphasis on manpower provided Field with the opportunity

\footnotetext{
${ }^{73}$ Parlimentary Debates (Lords), 509, 3 July 1989, 1013-15.

${ }^{74}$ General Synod (1985), 983.

${ }^{75}$ General Synod, February Group of Sessions, Report of Proceedings, vol. 12, no. 1 (London, 1981), 134-37.

${ }^{76}$ Parlimentary Debates (Commons), 167, 20 February 1990, 897, 901.

${ }^{77}$ General Synod (1985), 983.
} 
to argue that the Church's shortage of clerical personnel could be solved by allowing the ordination of women priests. ${ }^{78}$ His performance in parliament was clearly informed by his involvement with Broken Rites, but rested upon a rhetorical device in which the wronged clergy wife came potentially to stand for all women. Whilst Anglican women, particularly those married to men barred from ordination, were active in the formation of a support group for the $\mathrm{COM},{ }^{79}$ Field pleaded that 'before we discuss the rights of the wife of a person who wishes to be ordained, I hope that the House will have some respect for the rights and status of the woman who has been deserted by that person'. ${ }^{80}$ In 1986 diocesan bishops had been granted 'a general right to object to the institution of a priest to a living if he did not consider the appointment for any reason suitable' by the Patronage (Benefices) Measure. ${ }^{81}$ In theory, this discretionary power allowed a bishop to prevent the appointment of a priest who had committed adultery or otherwise treated his wife cruelly, but evidence gathered from members of Broken Rites convinced Field that in several cases priests had gained new livings, despite the assurance of the bishop to the contrary. During the meeting of the Ecclesiastical Committee in February 1989, Field speculated that these assurances 'might just be a line some bishops push to spin the wives along and comfort them'. ${ }^{82}$ Consequently, the spectre of a male episcopate being granted more discretionary power in this area determined Broken Rites's opposition to the COM. Despite this, the passage of the COM effectively allowed the broader issue of marriage in church after divorce to be decoupled from debates about the moral conduct

\footnotetext{
${ }^{78}$ Parlimentary Debates (Commons), 157, 17 July 1989, 181.

${ }^{79}$ Church Times, 5 August 1988, 14.

${ }^{80}$ Parliamentary Debates (Commons), 17 July 1989, 180-81.

${ }^{81}$ Ecclesiastical Committee, 10.

${ }^{82}$ Ecclesiastical Committee, 29. However, Field did acknowledge that gaining sufficient evidence against a clergyman was an issue.
} 
of clergymen. ${ }^{83}$ However, this did not diminish the public fascination with the private lives of clergy couples, as the response to The Rector's Wife revealed.

\section{Conclusion}

This article has demonstrated the difficulties the Church experienced adapting to the consequences of its own compromises in the permissive legislation of the 1960s, and of women's increasing autonomy and economic rights, however precarious, in the following decades. Perhaps inevitably, the Church contained a wide variety of opinions on matters of gender equality and sexuality in this period. Consequently, a lack of consensus militated against increasing numbers of divorced individuals being allowed to participate in a religious rite of passage which still mattered: a church wedding. As an established institution, the Church of England retained the right to speak out on a number of issues pertaining to the common good rather than its own constituency of worshippers. This status, combined with a failure to adequately address the new realities of divorce, only amplified existing tendencies to scrutinise the private lives of clergy families when marriages failed. By the early 1990s, The Rector's Wife had an even more willing audience. Both the perception of the 'permissive society' and the realities of greater sexual freedom beyond marriage placed added emphasis on the increasingly unworkable model of the clergyman as a moral exemplar, subjecting often fragile clerical masculinities to new pressures. Whilst the emphasis on professional stress helped acknowledge the strain of a vocation which

\footnotetext{
${ }^{83}$ Broken Rites continued to campaign on issues relevant to wives such as clergy discipline, pension rights and financial assistance, and gradually extended their remit to meet the needs of clergy husbands. Pauline Pearce, 'Secular and sacred journeys towards pension sharing at divorce', in Druiff and Murray, Story of Broken Rites, 30-31; Christine McMullen, 'The here and now', in Druiff and Murray, Story of Broken Rites, 3739; www.brokenrites.org. Accessed 26 August 2013.
} 
blurred the lines between public and private and no doubt provided much needed support, it also according to groups like Broken Rites deflected attention from the individual capacity for sin. For some abandoned clergy wives, the emphasis on compassion and forgiveness did not extend to their husbands. Understandably, this sense of resentment was compounded by their treatment at the hands of the Church. The deserted wife potentially stood as a potent reminder of her husband's actions, and complicated the process of rebuilding lives after the breakdown of a relationship. In a period associated with the protracted campaigns for women's ordination and the Church's grudging and incomplete accommodation of female vocational ambition, access to spiritual and emotional support as well economic rights were also important aspects of Christian women's agency in the late twentieth century.

9881 words 